\author{
MaŁgorzata Bajgier-Kowalska, Kamila WaŁACH \\ Krakowska Akademia im. A.F. Modrzewskiego, Polska • Andrzej Frycz Modrzewski Krakow \\ University, Poland
}

MARIOLA TRACZ

Polskie Towarzystwo Geograficzne, Oddział w Krakowie, Polska • Polish Geography Society, Department of Kraków, Poland

\title{
Międzynarodowe uwarunkowania rozwoju turystyki medycznej w Korei Południowej
}

\section{Global Determinants of the Development of Medical Tourism in South Korea}

\begin{abstract}
Streszczenie: Celem artykułu jest ukazanie stanu rozwoju turystyki medycznej w Korei Południowej, jej konkurencyjności oraz głównych ośrodków usług na tle międzynarodowych uwarunkowań rozwoju tej formy turystyki. W analizie wykorzystano dane z portali internetowych Koreańskiej Organizacji Turystyki, szpitali i klinik, agencji rządowych i turystycznych, a także z polskiej i obcojęzycznej literatury. Turystyka medyczna rozwija się w wielu krajach świata, wykorzystując z jednej strony kapitał ludzki i jego kwalifikacje oraz tradycje w zakresie leczenia, a z drugiej - walory środowiska przyrodniczego i kulturowego. Najczęściej wybieranymi przez turystów destynacjami w zakresie usług medycznych są kraje azjatyckie i latynoamerykańskie. W Azji Południowo-Wschodniej liderami w tej branży są głównie Indie, Tajlandia, Singapur oraz Malezja i Filipiny. Dużą konkurencją dla rynku usług medycznych tych państw staje się Korea Południowa, w której turystyka medyczna jest silnie promowana przez władze rządowe. Kraj ten z roku na rok zyskuje coraz większe zainteresowanie zagranicznych turystów, stając się obecnie jedną z ważniejszych i popularniejszych destynacji turystyki medycznej w tym regionie świata. W 2011 roku do Korei Południowej należało już ponad 6\% rynku turystyki medycznej Azji. Według oficjalnych statystyk w 2013 roku 210 tys. pacjentów zagranicznych skorzystało z usług południowokoreańskich szpitali i klinik. Odzwierciedlają to także przychody z tej działalności, które stanowiły 2,27\% udziału w ogólnych dochodach z turystyki tego kraju. Koreańska Organizacja Turystyki rekomenduje łącznie 132 szpitale, kliniki lub centra medyczne oraz 27 agencji specjalizujących się w pakietach turystyki medycznej spośród dużej ich liczby.
\end{abstract}

\footnotetext{
Abstract: The paper discusses the current state of medical tourism in South Korea, its degree of competitiveness, and primary centers of medical tourism in the context of global determinants of this form of tourism. The paper relies mostly on secondary sources of data such as official websites of hospitals, clinics, government agencies, tourism agencies, and the Korea Tourism Organization. Data provided by the research literature printed in Polish and in other languages were also used in the analysis. Medical tourism is growing in many countries around the world and takes advantage of human capital (i.e. qualified personnel) and local medical traditions. The local natural environment and cultural environment further contribute to this newly evolving trend. Countries in Asia and Latin America are most often selected by visitors for the purpose of medical tourism. Leading medical tourism countries in Southeast Asia are India, Thailand, Singapore, Malaysia, and the Philippines. South Korea is becoming a strong competitor in the medical services market in large part thanks to government support of this type of business. The number of non-local medical tourists visiting South Korea is growing with every year. South Korea is on its way to become a major medical tourism destination in this part of the world. In 2011 more than 6\% of this market belonged to South Korea. Official statistics indicate that 210,000 foreign patients were recorded to have taken advantage of services at South Korean hospitals and clinics in 2013. This is also reflected in tourism revenue: $2.27 \%$ of all revenue from tourism was ascribed to medical tourism. In fact, the Korea Tourism Organization recommends 132 hospitals, clinics, and medical
} 
centers as well as 27 agencies specializing in medical tourism packages, although the total number of such agencies as well as cooperating medical institutions in South Korea is much larger.

Słowa kluczowe: Korea Południowa; turystyka medyczna; turystyka zdrowotna; usługi turystyczne

Keywords: health tourism; medical tourism; South Korea; tourism service

Otrzymano: 20 grudnia 2015

Received: 20 December 2015

Zaakceptowano: 14 lipca 2016

Accepted: 14 July 2016

Sugerowana cytacja / Suggested citation:

Bajgier-Kowalska, M., Tracz, M., Wałach, K. (2016). Międzynarodowe uwarunkowania rozwoju turystyki medycznej w Korei Południowej. Prace Komisji Geografii Przemysłu Polskiego Towarzystwa Geograficznego, 30(4), 119-132.

\section{WSTĘP}

Proces globalizacji wpływa na rozwój i różnicowanie się usług turystycznych. Przejawem tego są nowe motywy i cele podróży, produkty oraz destynacje turystyczne. Rynek turystyczny, starając się dostosować do zachodzących zmian, proponuje coraz szerszą gamę ofert. Wzrastająca świadomość prozdrowotna społeczeństw, szczególnie postmodernistycznych, rosnące potrzeby samorealizacji i poprawy swojego wizerunku oraz dostępność usług medycznych powodują wzrost zainteresowania turystyką zdrowotną, w tym turystyką medyczną.

Termin „turystyka medyczna” został wprowadzony do literatury w latach dziewięćdziesiątych XX wieku. Najczęściej pod tym pojęciem rozumie się podróżowanie poza granice własnego kraju, którego celem jest poprawa zdrowia lub urody pod opieką lekarza specjalisty, połączone z wypoczynkiem, regeneracją sił fizycznych i psychicznych, a niekiedy zwiedzaniem oraz rozrywką (Kurek, 2008; Prochorowicz, 2008; Connell, 2010; 2013; Białk-Wolf, 2010; 2014; Levary, 2011; Han, 2013). Jest ona jedną z trzech - obok turystyki uzdrowiskowej oraz spa i wellness - form turystyki zdrowotnej. Na przełomie XX i XXI wieku głównie mieszkańcy bogatych państw europejskich, arabskich i Ameryki Północnej odbywali podróże w celach medycznych. Współcześnie turystyka medyczna udostępniona jest coraz szerszej grupie osób i staje się znaczącym ekonomicznie przedsięwzięciem, w które zaangażowane są zarówno prywatne, jak i państwowe szpitale, kliniki medyczne oraz firmy farmaceutyczne i turystyczne w wielu regionach świata. Również linie lotnicze i właściciele hoteli dostrzegają potencjał tego sektora turystyki, proponując zniżki i specjalne oferty osobom przyjeżdżającym na zabiegi medyczne (Carrera, Bridges, 2006; Kurek, 2008; Lunt i in., 2011; Rab-Przybyłowicz, 2014).

Większa popularność podróży w celach leczniczych powoduje, że turystyka medyczna jest jednym z dynamicznie rozwijających się usług tego sektora. Szacuje się, że w celach medycznych rocznie na całym świecie podróżuje ok. $5 \mathrm{mln}$ ludzi (Rab-Przybyłowicz, 2014; Youngman, 2015). Jednym z istotnych powodów uprawiania turystyki medycznej są wysokie ceny świadczeń w rodzimym kraju. Innym jest rządowy system ochrony zdrowia, kontrolujący dostęp do usług medycznych, w tym brak legalności 
niektórych zabiegów. Pacjenci decydują się na korzystanie z zagranicznych placówek medycznych w celu uniknięcia długoterminowego oczekiwania na zabieg we własnym kraju, z powodu niedostępności niektórych usług medycznych i niskiej ich jakości oraz dla zachowania prywatności i intymności podczas zabiegów (operacje plastyczne, zabiegi zmiany płci) (Horowitz, Rosensweig, Jones, 2007; Hopkins, Labonte, Runnels, Packer, 2010; Connell, 2011; 2013; Lubowiecki-Vikuk, 2012; 2015).

Turystyka medyczna rozwija się w wielu krajach świata. Do jej funkcjonowania niezbędny jest kapitał finansowy i ludzki oraz wsparcie władz, gdyż potrzebna jest także dobrze rozwinięta infrastruktura publiczna, tj. lotniska, drogi, kanalizacja, wodociągi oraz sektor usług specjalistycznych (usługi medyczne i edukacyjne) (Bookman, Bookman, 2007). Popularnymi kierunkami turystyki medycznej są: Azja Południowo-Wschodnia, Ameryka Środkowa i Południowa oraz Europa. Biorąc pod uwagę jakość usług medycznych, światowymi liderami w tej branży turystyki są Stany Zjednoczone Ameryki i Niemcy, natomiast rozpatrując aspekt kosztów - Indie, Tajlandia, Meksyk, Singapur, Kostaryka. Dużą konkurencją dla rynku usług medycznych tych państw są: Panama, Brazylia, Malezja, Filipiny, Turcja, Węgry, Polska oraz Korea Południowa (Levary, 2011; Lunt i in., 2011; Connel, 2013).

Celem niniejszego artykułu jest ukazanie stanu rozwoju turystyki medycznej w Korei Południowej, jej konkurencyjności oraz głównych ośrodków usług na tle międzynarodowych uwarunkowań jej rozwoju. W postępowaniu badawczym przeprowadzono analizę i interpretację materiałów źródłowych oraz dostępnych danych statystycznych. W celu uzupełnienia analizy źródeł oraz ukazania występujących zależności zastosowano metody kartograficzne. Wykorzystano materiały dostępne na oficjalnych portalach internetowych Koreańskiej Organizacji Turystyki, szpitali i klinik, agencji rządowych i turystycznych, a także materiał z polskiej i obcojęzycznej literatury. Ponadto dokonano przeglądu literatury w zakresie ewolucji pojęcia turystyki zdrowotnej i medycznej.

\section{TURYSTYKA MEDYCZNA JAKO FORMA TURYSTYKI ZDROWOTNEJ}

Przemiany w sferze wolnego czasu i warunków funkcjonowania społeczeństwa powodują duże różnicowanie się turystyki pod względem celu wyjazdu, kategorii społecznej uczestników, miejsca docelowego, sposobu realizacji, a także zakresu przestrzennego wyjazdów i czasu pobytu. Konsekwencją tego jest z jednej strony pojawianie się nowych form ruchu turystycznego, a z drugiej - nieścisłości terminologiczne w ich objaśnianiu i nazywaniu. Nieścisłości te wynikają także z dużej dynamiki zjawisk turystycznych oraz zainteresowania tą problematyką badaczy różnych dyscyplin naukowych (Gaworecki, 2007; Kurek, 2008; Rab-Przybyłowicz, 2014).

Turystyka zdrowotna ma wielowiekową tradycję, począwszy od indywidualnych wyjazdów „do wód”, po masowy współczesny ruch turystyczny. Znaczenie pojęcia turystyki zdrowotnej z czasem ewoluuje. Według J. Wolskiego (1970) pod tym pojęciem należy rozumieć świadome i dobrowolne udanie się na pewien okres poza miejsce zamieszkania, w czasie wolnym od pracy, w celu regeneracji organizmu, dzięki aktywnemu wypoczynkowi i rekreacji. Istotą wyjazdu jest więc poprawa czasowych niedomagań chorego, wynikająca najczęściej z przemęczenia fizycznego i psychicznego lub 
rekonwalescencji po przebytej chorobie. Natomiast A. Lewandowska (2007) rozszerza pojęcie turystyki zdrowotnej o usługi związane z poprawą urody i samopoczucia. Z kolei I. Łęcka (2003) definiuje turystykę zdrowotną jako wyjazd na dobę lub dłużej poza miejsce zamieszkania w celach regeneracyjnych, korekty urody, a także poddania się zabiegom w klinikach.

Biorąc pod uwagę zakres znaczeniowy, możemy w obrębie turystyki zdrowotnej wyróżnić trzy podgrupy: tradycyjną turystykę uzdrowiskową w zakładach lecznictwa uzdrowiskowego, turystykę spa i wellness oraz turystykę medyczną. Te nowe usługi zdrowotne są odpowiedzią na potrzeby społeczeństw konsumpcyjnych w zakresie poprawy zdrowia i urody lub rehabilitacji i odnowy psychofizycznej (Łęcka, 2003; Henderson, 2004; Kurek, 2008; Rab-Przybyłowicz, 2014). Pojęcie turystyki medycznej jest tożsame z pojęciem globalnej opieki zdrowotnej (ang. global healthcare), gdzie zjawisko to nie odnosi się do opieki w przypadku zagrożenia zdrowia podczas pobytu pacjenta za granicą, lecz do głównego motywu jego wyjazdu - aspektu medycznego (Lunt, Carrera, 2010; Lubowiecki-Vikuk, 2015).

Turystyka medyczna, podobnie jak współczesna turystyka międzynarodowa, podlega silnej segmentacji, oferując wiele wyspecjalizowanych usług. Odpowiada na zmieniające się potrzeby i motywy wyjazdów indywidualnych turystów oraz wzrost ich wymagań co do jakości oferowanych usług. Do najpopularniejszych usług turystyki medycznej należą operacje plastyczne, zabiegi stomatologiczne i kardiochirurgiczne oraz leczenie bezpłodności (Bookman, Bookman, 2007; Kurek, 2008; Connell, 2010; 2011; Lunt i in., 2011).

Współczesny rozwój technologii, zwłaszcza sieci internetowej, sprzyja promowaniu turystyki medycznej, a także ułatwia dostęp do informacji dotyczących różnorodnych ofert tej branży. Rozwój internetowych biur podróży umożliwia klientom szczegółowe poznanie oferty i tworzenie indywidualnego pakietu turystyki medycznej.

Na rozwój współczesnej turystyki medycznej istotny wpływ mają koszty usług medycznych w poszczególnych krajach, ich jakość oraz marketing szeptany i internetowy, jak również rozwój tanich form podróżowania (Gan, Frederick, 2011; Connell, 2013; Yeoh, Othman, Ahmad, 2013; Białk-Wolf, 2014). Szczególny udział w turystyce medycznej mają kraje, gdzie tradycyjne lecznictwo jest stosowane od dawna.

\section{Ruch turystyczny W Korei PoŁudniowej nA tLe AzjI I OCEANiI}

Korea Południowa należy do regionu turystycznego Azji i Oceanii, który w 2014 roku odnotował jeden z największych wzrostów liczby turystów (+5\%) w stosunku do 2013 roku. Region ten odwiedziło 263 mln turystów, a dochód z turystyki wyniósł 277 mld dol., co daje 30\% światowego dochodu. W subregionie północno-wschodniej Azji do państw, które osiągnęły najwyższy wzrost liczby turystów, należą: Japonia (+29\%), Tajwan (+24\%) i Korea Południowa (+17\%) (UNWTO Tourism Highlights, 2015).

Dla rozwoju turystyki przyjazdowej i promocji Korei Południowej na rynkach zagranicznych miało znaczenie organizowanie przez ten kraj ważnych wydarzeń sportowych. Były to Letnie Igrzyska Olimpijskie w Seulu (1988), które spowodowały, że w tym roku do Korei przybyło ponad 2 mln turystów. Kolejną imprezą były Mistrzostwa 
Świata w Piłce Nożnej (2002) organizowane wraz z Japonią. W roku tym Koreę Południową odwiedziło ponad 5,3 mln turystów. Należy jednak nadmienić, iż w miesiącach, w których organizowano imprezę, odnotowano najmniej turystów w całym 2002 roku. Ważną imprezą sportową organizowaną w Korei Południowej były Mistrzostwa Świata w Lekkoatletyce (2011) w mieście Daegu, położonym w południowo-wschodniej części kraju. W roku tym liczba turystów odwiedzających Koreę wyniosła już ponad 9,7 mln osób, a w 2013 roku przekroczyła $12 \mathrm{mln}$. Innym międzynarodowym wydarzeniem sportowym odbywającym się w Korei Południowej były Asian Games (2014) w Incheon. W 2014 roku kraj ten odwiedziło 14,2 mln turystów zagranicznych, głównie z regionu Azji i Oceanu Spokojnego. Trzeba podkreślić, że w latach 1980-2014 w Korei Południowej odnotowano ponad czternastokrotny wzrost liczby turystów, gdy dla Azji i Oceanii w tym okresie liczba turystów wzrosła tylko 11,5 razy (ryc. 1) (Tourism Statistics, 2015).

Ryc. 1. Procentowy wzrost liczby turystów zagranicznych w Korei Południowej oraz w regionie Azji i Oceanii względem roku 1980

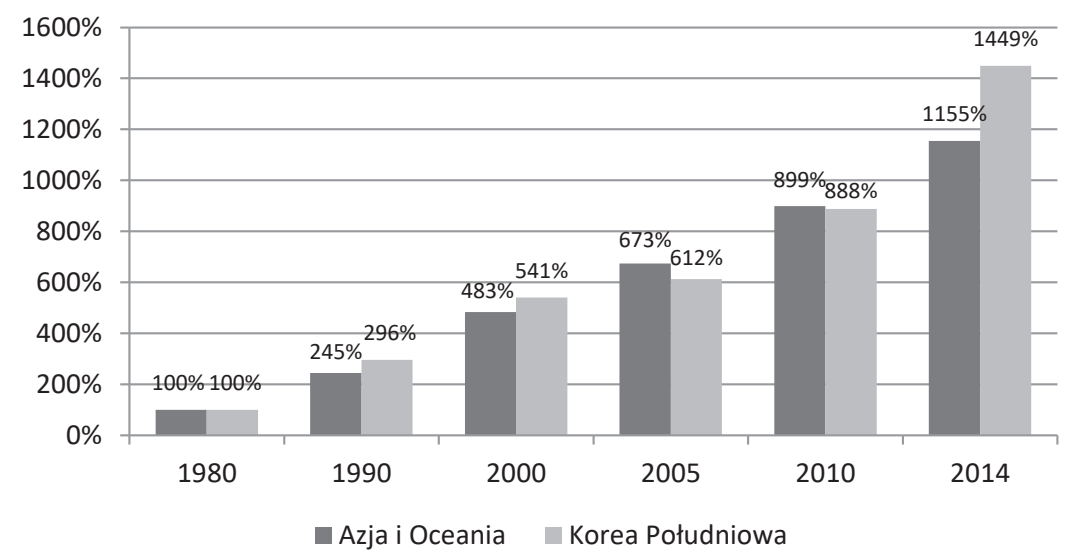

Źródło: opracowanie własne na podstawie: UNWTO Tourism Highlights (2015: 4) oraz Tourism Statistics (2015)

Wystąpienie wirusa MERS (Middle East Respiratory Syndrome - bliskowschodniego zespołu niewydolności oddechowej), którego przypadki odnotowano po raz pierwszy w Korei 20 maja 2015 roku, nie pozostało bez wpływu na liczbę przyjazdów turystów zagranicznych. W czerwcu 2015 roku liczba turystów spadła o 41\% w porównaniu z czerwcem 2014 roku. Również zestawienie danych z lipca 2014 i 2015 roku wskazuje na dalszy spadek liczby turystów, który wynosił -53,5\% (Visit Medical Corea, 2015). Koreańskie Centrum Zwalczania Chorób i Zapobiegania przewidywało, iż Korea Południowa powinna być wolna od wirusa MERS w połowie września 2015 roku. W tej sytuacji Koreańska Organizacja Turystyki wprowadziła w lipcu 2015 roku studniowy plan odbudowy turystyki w kraju. Polegał on m.in. na promowaniu Korei w zagranicznych mediach poprzez spoty reklamowe (np. w telewizji CNN) oraz organizowaniu wycieczek po Seulu dla azjatyckich przedstawicieli agencji turystycznych, dziennikarzy i blogerów. Kolejne przypadki zachorowań na wirusa MERS pojawiły się w październiku 2015 roku, co przypuszczalnie wpłynęło na zachowania turystów zagranicznych. 


\section{Turystyka medyczna W Korei PoŁudniowej}

Korea Południowa jest przykładem państwa, w którym turystyka staje się coraz istotniejszym czynnikiem rozwoju. Koreańska Organizacja Turystyki realizuje rządowy program Imagine Your Korea, którego celem jest promowanie kraju za granicą, w tym ofert turystyki medycznej. Turystyka ta została przez rząd koreański umieszczona w planach wzrostu gospodarczego kraju, jak również w przepisach wizowych (Lunt i in., 2011).

Opracowano stronę internetową Visit Medical Korea, która rekomenduje wybrane szpitale, kliniki oraz centra medyczne. Łącznie prezentowane są informacje o 132 obiektach. Wśród nich wyróżnione są te, którym zostały przyznane certyfikaty. Pierwszy z nich przyznaje International Hospital Evaluation Group szpitalom spełniającym międzynarodowe wymogi. Drugi certyfikat potwierdza legalność działających klinik i nadawany jest przez Ministerstwo Sprawiedliwości. Trzeci z certyfikatów nadawany jest przez rząd na cztery lata placówkom medycznym, które podniosły znacząco jakość świadczonych usług. Ponadto na wspomnianej stronie znajdują się nazwy 36 agencji specjalizujących się w pakietach turystyki medycznej i 13 usługodawców powiązanych z turystyką medyczną.

W Korei Południowej działa wiele agencji turystycznych specjalizujących się w turystyce medycznej, ale tylko 27 biur rekomendowanych jest przez Koreańską Organizację Turystyczną. Zapewniają one klientom transport pomiędzy lotniskiem, hotelem a kliniką, jak również pomoc w załatwieniu wszystkich formalności związanych z leczeniem, np. uzyskanie wizy, pomoc tłumacza itp. Do najbardziej znanych agencji należy Seoul Touch Up, zajmująca się głównie turystyką medyczną w zakresie operacji plastycznych i oferująca zróżnicowane pakiety usług medycznych (Visit Medical Korea, 2015).

Od 2007 roku obserwuje się rosnące zainteresowanie turystów zagranicznych turystyką medyczną w Korei Południowej, co wyraża się rosnącą liczbą pacjentów korzystających z usług południowokoreańskich szpitali i klinik (ryc. 2).

Ryc. 2. Liczba turystów zagranicznych przybywających do Korei Południowej w celu uzyskania pomocy medycznej w latach 2007-2013

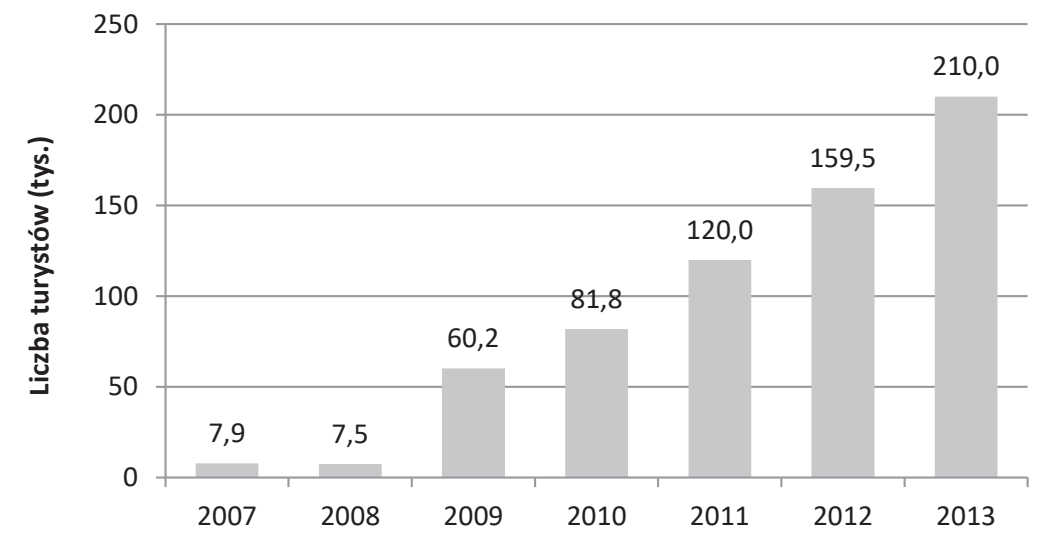

Źródło: opracowanie własne na podstawie: Ulloa (2012) i Medical Tourism Association (2015) 
Wyraźny wzrost liczby turystów notowany jest od 2009 roku. W roku tym do Korei przybyło 60,2 tys. osób, a w 2013 roku było już 210 tys. turystów. W analizowanym okresie wystąpił ponad trzykrotny wzrost liczby turystów medycznych. Odzwierciedlają to także przychody uzyskiwane z tytułu tej działalności (ryc. 3). W latach 2006-2010 wzrost ten był na zbliżonym poziomie, natomiast wyraźny skok nastąpił w roku 2013, w którym dochody z turystyki medycznej podwoiły się w porównaniu z rokiem 2012. Przychód z turystyki medycznej to średnio 1,1\% całych przychodów z turystyki w Korei Południowej.

W badanym okresie najwyższe wpływy z turystyki medycznej zostały osiągnięte w 2013 roku i stanowiły 2,27\% udziału w ogólnych dochodach z turystyki w tym roku (ryc. 4). Według szacunków Koreańskiej Organizacji Turystyki przychód z turystyki medycznej w 2020 roku może wynieść nawet 3,2 mld dol.

Ryc. 3. Przychód z turystyki medycznej w Korei Południowej w latach 2006-2014 (mln dol.)

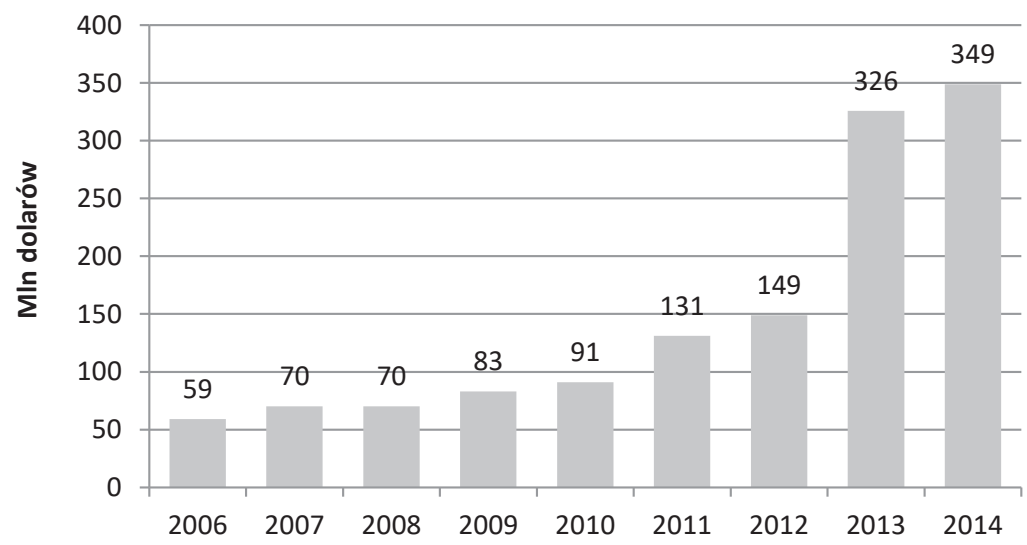

Źródło: opracowanie własne na podstawie danych z Ulloa (2012), International Medical Travel Journal (2015), Want China Times (2015)

Ryc. 4. Przychód z turystyki medycznej na tle przychodów z turystyki w Korei Południowej w latach 20062013

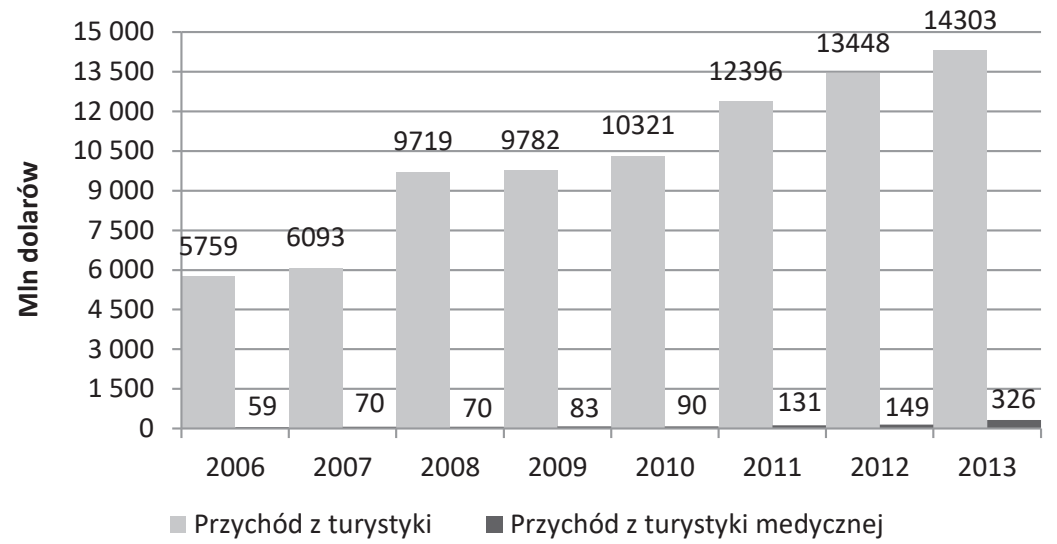

Źródło: opracowanie własne na podstawie danych ze strony internetowej Koreańskiej Organizacji Turystyki (Tourism Statistics, 2015) 
Ryc. 5. Rozmieszczenie portów lotniczych oraz głównych ośrodków medycznych w Korei Południowej

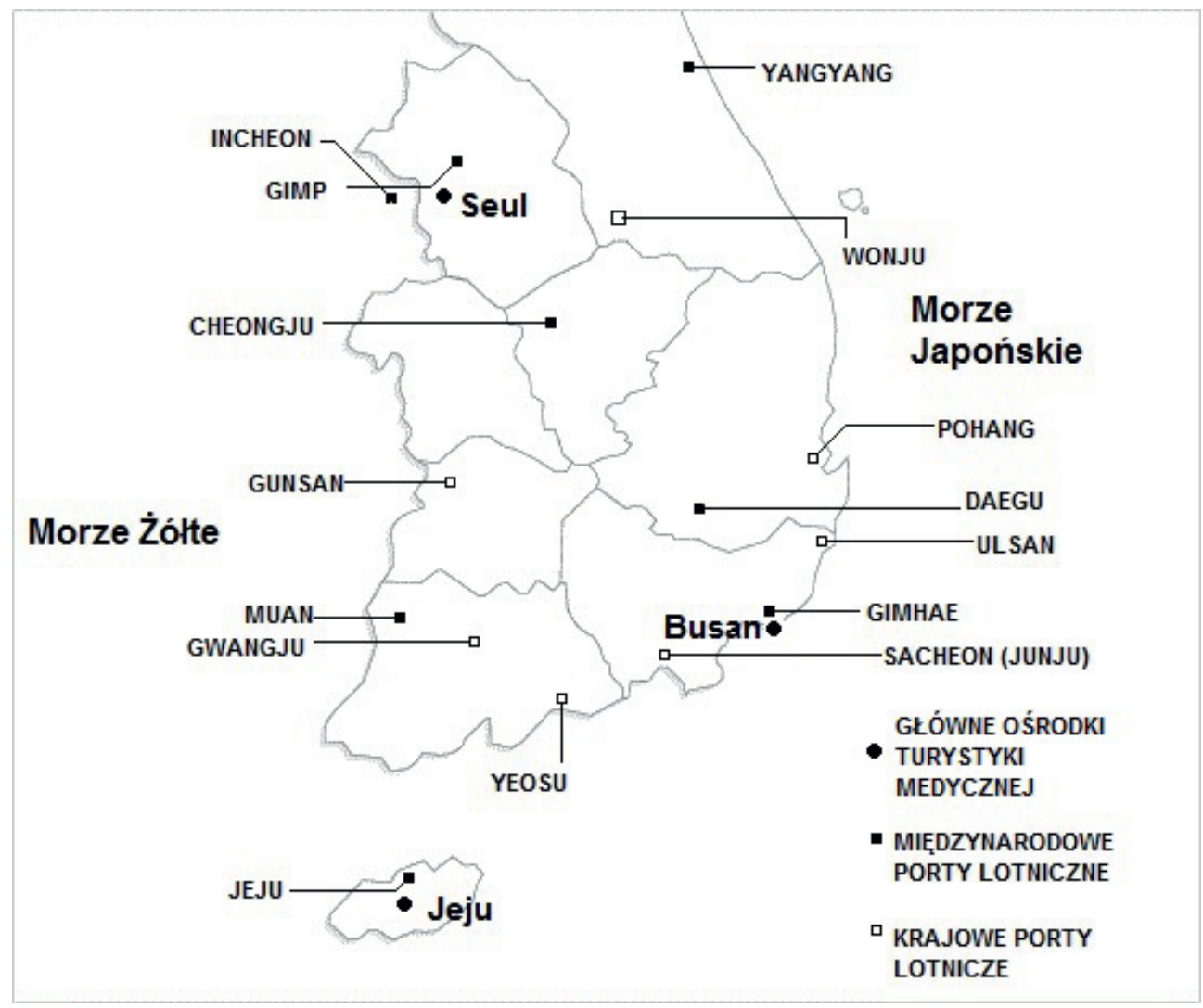

Źródło: opracowanie własne

W Korei Południowej jest kilka ośrodków przyciągających wielu turystów medycznych. Głównym takim miejscem jest stolica kraju - Seul. Funkcjonują tu 92 kliniki (wg oficjalnych statystyk) specjalizujące się głównie w chirurgii plastycznej (Plastic Surgery Clinics Seoul, 2015). Usługi i zabiegi medyczne są tu szeroko reklamowane, w tym na stacjach metra w najbogatszej dzielnicy Seulu - Gangnam. Drugim popularnym ośrodkiem jest miasto Busan (Pusan). Znajduje się tu siedem klinik chirurgii plastycznej, zlokalizowanych przy ulicy Seomyeon, tzw. medycznej ulicy. Trzecim ośrodkiem jest wyspa Jeju. Funkcjonują tu trzy szpitale specjalizujące się w chirurgii plastycznej oraz 10 klinik oferujących różnorodne usługi. Planowane jest również otwarcie w 2018 roku dużego centrum medycznego Jeju Healthcare Town, w którym obok kompleksu medycznego będzie funkcjonował kompleks spa i wellness (Ueju Special..., 2015). Należy nadmienić, iż są to regiony o dużych walorach turystycznych, w których zachował się bogaty dorobek kulturowy i tradycje, a także mało przekształcone środowisko naturalne.

Rozwojowi usług medycznych w Korei Południowej sprzyja bardzo dobrze rozwinięta sieć połączeń lotniczych, kolejowych i autobusowych. W kraju funkcjonuje osiem międzynarodowych portów lotniczych: Incheon, Gimpo, Gimhae, Cheongju, Daegu, 
Muan, Yangyang i Jeju, oraz siedem portów krajowych (ryc. 5). Port lotniczy w Incheon ma połączenia z większością krajów świata, a pozostałe oferują głównie loty w regionie Azji. Turyści mogą także korzystać z rozwiniętej sieci linii kolejowych, w tym z głównej magistrali kolejowej Seul-Busan-Kwangju, oraz sieci połączeń ekspresowych (KTX), łączących największe miasta Korei (Seul, Daejeon, Daegu i Busan).

\section{KonkURENCYjNoŚć KoREI POŁUdNIOWEJ NA RYNKU USŁUG TURYSTYKI MEDYCZNEJ}

Korea Południowa jest krajem, w którym odnotowuje się najwyższą liczbę zabiegów kosmetycznych przypadającą na 1000 mieszkańców. Już w 2011 roku w rankingu tym wyprzedziła ona takie kraje, jak Grecja, Włochy i USA (Korean Plastic Surgery Statistics, 2015). Daje to koreańskim chirurgom średnio o 1,7 raza więcej zabiegów rocznie niż chirurgom na Tajwanie, o 6,9 niż chirurgom tajlandzkim oraz 17 razy więcej zabiegów od chirurgów chińskich. Jest to jeden z powodów stale wzrastającego zainteresowania turystyką medyczną mieszkańców Korei jak i turystów zagranicznych.

Dla Koreańczyków wygląd jest bardzo ważny i aby osiągnąć upragnioną aparycję skłonni są do wielu poświęceń. To zamiłowanie do korekty swojego wyglądu wywodzi się z kanonu piękna obowiązującego w tym kraju. Również media i celebryci mają duży udział w kreowaniu wizji ideału piękna, a to skłania społeczeństwo do zmiany swojego wyglądu. Wielu Koreańczyków poddaje się zabiegom chirurgii plastycznej, gdyż wierzą, że dobry wygląd wpływa na ich sukcesy zarówno w życiu zawodowym, jak i prywatnym.

Statystyki pokazują, że jedna na pięć koreańskich kobiet poddała się przynajmniej jednej operacji plastycznej (w Stanach Zjednoczonych Ameryki jest to jedna na 20 kobiet) (Chang, Thompson, 2014). W 2014 roku mieszkańcy Korei Południowej wydali na chirurgiczne zabiegi kosmetyczne 5 mld dol., co stanowi aż 24\% dochodów z chirurgii plastycznej na świecie (Korean Plastic Surgery Statistics, 2015). Do najpopularniejszych operacji wśród ludności południowokoreańskiej należą zabieg tzw. podwójnej powieki, czyli uzyskania efektu większego oka, oraz operacja poprawiająca kształt szczęki (w celu uzyskania linii „V”). Równie popularnymi zabiegami są przeszczep włosów i konturowanie kształtu twarzy (8 Most Popular Plastic Surgery..., 2015).

Jednym z czynników, dla których turyści decydują się na przyjazd do Korei Południowej, jest wykonywanie w klinikach i szpitalach operacji plastycznych, które bardzo często są nielegalne bądź zwyczajnie nie są praktykowane w wielu krajach świata. Przykładem może być zabieg zmiany kości twarzy, którego wykonanie wymaga dużego doświadczenia i umiejętności. Mocną stroną koreańskiej branży turystyki medycznej są więc wysokie kwalifikacje personelu medycznego oraz oferta zaawansowanych usług medycznych z wykorzystaniem najnowszych technologii. Specjalistyczne usługi, oprócz chirurgii plastycznej, obejmują leczenie raka, układu krążenia, niepłodności oraz okulistykę (Kim, Lee, Jung, 2013).

Istotnym powodem wzrostu popularności Korei Południowej na mapie turystyki medycznej są niższe koszty zabiegów. Informacje o cenach oferowanych zabiegów medycznych są zamieszczone m.in. na stronie internetowej Korea Medical Hub, która istnieje od 2011 roku. Warto podkreślić, iż oficjalnymi partnerami tej instytucji są 
Ministerstwo Zdrowia i Opieki Społecznej oraz Koreańska Organizacja Turystyki. Analiza cen zabiegów oferowanych przez koreańskie kliniki wykazała, że są one niższe niż ceny tych samych zabiegów wykonywanych w krajach europejskich i USA. Przykładowo zabieg klasycznego liftingu twarzy w Korei Południowej kosztuje średnio o 4 tys. zł mniej niż w klinikach amerykańskich. Zbliżone różnice w cenie odnotowano także dla innych oferowanych zabiegów (Plastic Surgery Price Korea, 2015).

Według Ministerstwa Zdrowia i Opieki Społecznej Korei Południowej turyści medyczni w 2013 roku pochodzili ze 191 państw. Największy wzrost zanotowano wśród obywateli Rosji. W 2013 roku przybyło ich o 46\% więcej niż rok wcześniej. Duży wzrost liczby turystów odnotowano również wśród obywateli Chin. W 2013 roku było ich o 28\% więcej niż w roku 2010. Stanowili oni największą grupę turystów medycznych odwiedzających Koreę Południową (ryc. 6).

Na drugim miejscu od wielu lat są turyści ze Stanów Zjednoczonych, wśród których znaczną liczbę stanowią Koreańczycy na stałe mieszkający w USA oraz żołnierze stacjonujący na terenie Korei Południowej. Znaczny wzrost turystów medycznych nastąpił również wśród obywateli Zjednoczonych Emiratów Arabskich. W 2012 roku ich liczba wynosiła 342, a w 2013 - już 1151 osób. Daje to wzrost o blisko 236\%. Większość z tych pacjentów przybywa na leczenie do Korei Południowej w ramach porozumienia zawartego pomiędzy opieką zdrowotną Zjednoczonych Emiratów Arabskich a południowokoreańskimi instytucjami medycznymi (Suh, 2015).

Ryc. 6. Liczba turystów medycznych odwiedzających Koreę Południową w 2013 roku według narodowości

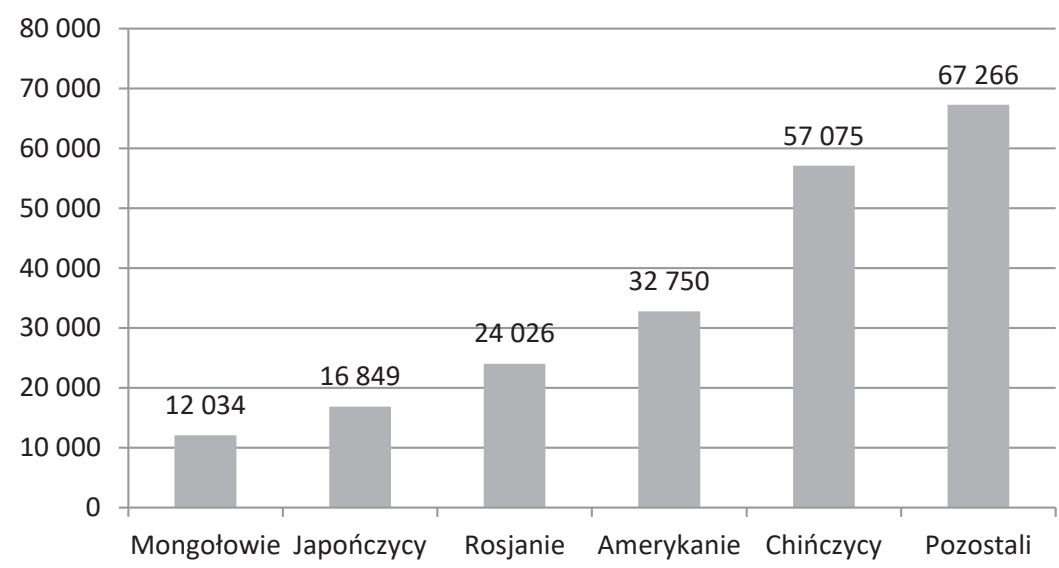

Źródło: opracowanie własne na podstawie Medical Tourism Association (2015)

\section{PoDSUMOWANIE}

Azja i Oceania to region, w którym wg prognoz liczba przyjazdów turystycznych będzie systematycznie wzrastać. Już teraz jest to jeden z najszybciej rozwijających się regionów na świecie, a pod względem liczby przyjazdów turystycznych znajduje się w światowej czołówce. Obserwowany jest również stały wzrost zainteresowania turystyką medyczną w tym regionie. Liczba turystów medycznych w Korei Południowej 
zwiększa się z każdym rokiem, co związane jest głównie z dostępnością i wysoką jakością specjalistycznych usług wykorzystujących najnowsze technologie oraz z konkurencyjnymi cenami. Innym z ważniejszych czynników stymulujących rozwój turystyki, w tym medycznej, jest liberalna polityka wjazdowa. Koreańska Organizacja Turystyki prognozuje, że w 2015 roku z turystyki medycznej w tym kraju skorzysta ok. 300 tys., a w 2020 roku ok. 1 mln osób (Ulloa, 2012).

Rząd Korei Południowej traktuje turystykę medyczną jako jeden z kierunków rozwoju gospodarczego kraju, dlatego Bank Centralny (Bank of Korea) od 2006 roku prowadzi jej statystyki. Mają one służyć kształtowaniu polityki gospodarczej, w tym polityki turystycznej państwa. Warto odnotować, iż liczba turystów medycznych podawana w oficjalnych statystykach koreańskich jest nieadekwatna do stanu faktycznego, co wiąże się z rozwojem nielegalnych usług medycznych i chęcią uzyskania przez turystów tanich zabiegów. Istnieje grupa turystów (trudna do oszacowania) zainteresowana ominięciem procedur formalnoprawnych przeprowadzanych zabiegów medycznych oraz ich późniejszych konsekwencji. Powodem może być fakt, iż po wielu zabiegach pacjent nie może przez określony czas korzystać z transportu lotniczego, w związku z czym zataja dane o przebytych operacjach.

Według szacunków w 2014 roku w Korei Południowej funkcjonowało blisko 20 tys. niezarejestrowanych chirurgów, a liczba zarejestrowanych była poniżej 2000 . Korzystanie z usług chirurgów, którzy nie są ewidencjonowani w agencjach rekomendowanych przez Koreańskie Ministerstwo Zdrowia, często łączy się z wykorzystywaniem nielegalnych pośredników medycznych. Ceny proponowane przez takie agencje, których liczba ciągle wzrasta, są dużo niższe od cen podawanych przez agencje polecane przez koreański rząd (Xinhua News Agency, 2015).

Korea Południowa prowadzi intensywną promocję ofert turystyki medycznej w kraju i za granicą. Dostępne są specjalistyczne strony internetowe i przewodniki online, z których można uzyskać wszelkie informacje na temat oferowanych usług. Pomocne są również biura informacji turystycznej, które działają na wszystkich międzynarodowych lotniskach. Istnieje także opracowana w czterech językach specjalna aplikacja na telefon (MediApp Korea) oraz centrum turystycznej informacji medycznej Medical Tourism Information Center na lotnisku Seul-Inczhon. Kierują one przyjezdnych do klinik specjalizujących się w chirurgii plastycznej, stomatologii, leczeniu niepłodności, medycynie orientalnej i innych usługach medycznych. Promocji turystyki medycznej w Korei Południowej posłużą zapewne organizowane w 2018 roku Zimowe Igrzyska Olimpijskie w Pyeongchang oraz stale wzrastające zainteresowanie koreańską kulturą popularną.

\section{Literatura}

References

8 Most Popular Plastic Surgery Procedures in Korea (2015, 6 października). Pozyskano z http:// www.koreaboo.com/spotlight/8-most-popular-plastic-surgery-procedures-in-korea/

Białk-Wolf, A. (2010). Potencjał rozwojowy turystyki medycznej. Zeszyty Naukowe Uniwersytetu Szczecińskiego, 591, 653-662.

Białk-Wolf, A. (2014). Turystyka medyczna. Perspektywy rozwoju w woj. pomorskim. Pozyskano z http://www.gdansk4u.pl/uploads/TurystykaMedycznaRaport.pdf 
Bookman, M.Z., Bookman, K.R. (2007). Medical Tourism in Developing Countries. New York: Palgrave MacMillan.

Carrera, P., Bridges, J. (2006). Globalization and healthcare: understanding health and medical tourism. Expert Review of Pharmacoeconomics and Outcomes Research, 6, 447-454.

Chang, J., Thompson, V. (2014) (2015, 7 października). South Korea's Growing Obsession with Cosmetic Surgery. Pozyskano z http://abcnews.go.com/Lifestyle/south-koreas-growing-obsession-cosmetic-surgery/story?id=24123409

Connell, J. (2010). Medical Tourism. UK: Cabi.

Connell, J. (2011). A new inequality? Privatisation, urban bias, migration and medical tourism, Asia Pacific Viewpoint, 52(3), 260-271.

Connell, J. (2013). Contemporary medical tourism: Conceptualisation, culture and commodification. Tourism Management, 34, 1-13.

Gan, L.L., Frederick, J.R. (2011). Medical tourism facilitators: Patterns of service differentiation. Journal of Vacation Marketing, 17(3), 165-183.

Gaworecki, W. (2007). Turystyka. Warszawa: Polskie Wydawnictwo Ekonomiczne.

Han, H. (2013). The healthcare hotel: Distinctive attributes for international medical travelers. Tourism Management, 36, 257-268.

Henderson, J. (2004). Healthcare Tourism in Southeast Asia. Tourism Review International, 7(3-4), 111-121.

Hopkins, K., Labonte, R., Runnels, V., Packer, C. (2010). Medical tourism today: what is the state of existing nowledge? Journal of Public Health Policy 31(2), 185-198.

Horowitz, M.D., Rosensweig, J.A., Jones, Ch.A. (2007). Medical Tourism: Globalization of the Healthcare Marketplace. MedGenMed, 9(4), 1-33. Pozyskano z http://www.ncbi.nlm.nih. gov/pmc/articles/PMC2234298/

International Medical Travel Journal (2015, 20 grudnia). Pozyskano z http://www.imtj.com/ news $/$ ?entryid82 $=355073$

Jeju Special Self Governing Province (2015, 10 września). Pozyskano z http://english.jeju.go.kr/

Kim, S., Lee, J., Jung, J. (2013). Assessment of medical tourism development in Korea for the achievement of competitive advantages. Asia Pacific Journal of Tourism Research, 18(5), 421-445.

Korean Plastic Surgery Statistics (2015, 6 października). Pozyskano z https://www.seoultouchup. com/korean-plastic-surgery-statistics/

Kurek, W. (2008). Turystyka. Warszawa: PWN.

Levary, R.R. (2011). Multiple-Criteria Approach to Ranking Medical Tourism Destinations. Thunderbird International Business Review, 53(4), 529-537.

Lewandowska, A. (2007). Turystyka uzdrowiskowa. Szczecin: Wydawnictwo Naukowe Uniwersytetu Szczecińskiego.

Lubowiecki-Vikuk, A.P. (2012), Turystyka medyczna przejawem współczesnych trendów i tendencji w turystyce. Zeszyty Naukowe Uniwersytetu Szczecińskiego, 699, Ekonomiczne Problemy Usług, 84, 553-568.

Lubowiecki-Vikuk, A.P. (2015). Specyficzność turystyki medycznej. W: G. Godlewski, M. Zalech (red.). Turystyka kontrowersyjna na współczesnym rynku podróży - formy, uwarunkowania, skutki. Biała Podlaska: Akademia Wychowania Fizycznego, 163-172.

Lunt, N., Carrera, P. (2010). Medical tourism: Assessing the evidence on treatment abroad. Maturitas, 66, 27-32.

Lunt, N., Smith, R., Exworthy, M., Green, S.T., Horsfall, D., Mannion, R. (2011). Medical Tourism: Treatments, Markets and Health System Implications: A scoping review. Pozyskano z http:// www.oecd.org/els/health-systems/48723982.pdf

Łęcka, I. (2003). Nowe (?) trendy w turystyce zdrowotnej. Prace i Studia Geograficzne. Geografia turyzmu, 32, 174-190. 
Medical Tourism Association (2015, 20 grudnia). Pozyskano z http://www.medicaltourismassociation.com/en/research-and-surveys.html

Plastic Surgery Clinics Seoul (2015, 15 września). Pozyskano z http://www.whatclinic.com/cosmetic-plastic-surgery/south-korea/seoul

Plastic Surgery Price Korea (2015, 20 grudnia). Pozyskano z www.kmhglobal.com/plastic-surgery-price-korea

Prochorowicz, M. (2008). Turystyka medyczna nową perspektywą dla polskich placówek służby zdrowia. W: R. Grzywacz (red.). Turystyka i rekreacja szansq̨ rozwoju aktywności społecznej. Rzeszów: Wydawnictwo Wyższej Szkoły Informatyki i Zarządzania.

Rab-Przybyłowicz, J. (2014). Produkt turystyki medycznej. Warszawa: Wydawnictwo Difin.

Suh, E.C. (2015, 25 września). South Korea: Medical Tourism. Pozyskano z https://brandeisear. wordpress.com/2014/10/04/south-korea-medical-tourism/

Tourism Statistics (2015, 20 września). Korea Tourism Organization. Pozyskano z http://kto.visitkorea.or.kr/eng/tourismStatics/keyFacts/KoreaMonthlyStatistics/eng/inout/inoutkto

Ulloa, S. (2012). Korea Health Tourism Sector Hits Milestone. Pozyskano z http://www.globalsurance.com/news/2012/02/13/korea-health-tourism-sector-hits-millestone

UNWTO Tourism Highlights 2015 Edition (2015, 20 grudnia). Pozyskano z http://www.e-unwto. org/doi/pdf/10.18111/9789284416899

Visit Medical Korea (2015, 15 września). Pozyskano z http://english.visitmedicalkorea.com

Want China Times (2015, 20 grudnia). Pozyskano z http://www.wantchinatimes.com/news-subclass-cnt.aspx?id=20150212000056\&cid=1103, http://www.imtj.com/news/?entryid $82=355073$

Wolski, J. (1970). Turystyka zdrowotna a uzdrowiska europejskich krajów socjalistycznych. Problemy Uzdrowiskowe, 5.

Xinhua News Agency (2015, 8 listopada). Feature: South Korea's medical tourism revenue slips amid growing malpractice. Pozyskano z http://www.china.org.cn/world/Off_the_Wire/201502/10/content_34786781.htm

Yeoh, E., Othman, K., Ahmad, H. (2013). Understanding medical tourists: Word-of-mouth and viral marketing as potent marketing tools. Tourism Management, 34, 196-201.

Youngman, I. (2015, 6 listopada). Medical Tourism Research: Facts And Figures 2015. International Medical Travel Journal. Pozyskano z http://www.imtj.com/resources/medical-tourism-research-facts-and-figures-2015/

Małgorzata Bajgier-Kowalska, doktor, adiunkt, Krakowska Akademia im. Andrzeja Frycza Modrzewskiego, Wydział Prawa, Administracji i Stosunków Międzynarodowych, Katedra Turystyki Międzynarodowej i Geografii Społecznej. Zainteresowania naukowo-badawcze i tematyka publikacji koncentrują się wokół problemów geomorfologicznych oraz zagadnień z zakresu geografii regionalnej. Badania autorki koncentrują się również na problematyce rozwoju turystyki i rekreacji, a głównie na zagadnieniach uwarunkowania rozwoju i funkcjonowania regionów turystycznych na świecie, analizie przestrzennego zróżnicowania zagospodarowania turystycznego oraz wielkości ruchu turystycznego.

Małgorzata Bajgier-Kowalska, Ph.D., assistant professor, Andrzej Frycz Modrzewski Krakow University, Faculty of Law, Administration and International Relations, Department of International Tourism and Sociological Geography. Her research issues and publication themes are concentrated on the geomorphology problems and the issues concerning regional geography. The author's research concentrate also on the problem of tourism and recreation growth, especially on the question of development conditions and functioning of tourist regions in the world including the analyses of spatial differentiation of tourist infrastructure and size of tourism itself.

Kamila Wałach, magister, absolwentka Krakowskiej Akademii im. Andrzeja Frycza Modrzewskiego. Zainteresowania badawcze koncentrują się na turystyce międzynarodowej, w tym szczególnie na regionie Azji. 
Kamila Wałach, M.Sc., graduate of the Andrzej Frycz Modrzewski Krakow University, Faculty of Law, Administration and International Relations. The author's research interest are concentrating on the international tourism, particularly on the region of Asia.

\section{Adres/address:}

Krakowska Akademia im. Andrzeja Frycza Modrzewskiego

Wydział Prawa, Administracji i Stosunków Międzynarodowych

ul. Gustawa Herlinga-Grudzińskiego 1, 30-705 Kraków, Polska

e-mail: malbajkow@interia.pl (Małgorzata Bajgier-Kowalska)

e-mail: walach_kamila@interia.pl (Kamila Wałach)

Mariola Tracz, doktor, geograf, dydaktyk geografii, członkini Polskiego Towarzystwa Geograficznego. Zainteresowania naukowe skupiają się wokół dydaktyki geografii (programy nauczania, edukacja geograficzna a kształtowanie kompetencji, historia geografii i jej dydaktyka), geografia społeczno-gospodarcza (polityka edukacyjna państwa, edukacja a rozwój gospodarczy).

Mariola Tracz, Ph.D., geographer, geography didactician, member of the Polish Geographical Society. Interests include: geographical education (geography curriculum, development of geography competency, geography on examination, history of geography education in Poland) and socio-economic geography.

\section{Adres/address:}

Polskie Towarzystwo Geograficzne, Kraków

Oddział w Krakowie

ul. Podchorążych 2

30-084 Kraków

e-mail: mtracz-62@o2.pl 